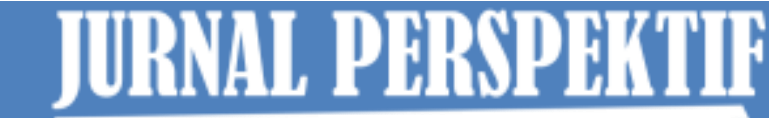 Junal Käjan Sosiogogi ian Pendidiken}

Jurnal Perspektif: Jurnal Kajian Sosiologi dan Pendidikan Vol. 4 No. 4 Tahun 2021

http://perspektif.ppj.unp.ac.id

Email: perspektif@ppj.unp.ac.id

ISSN: 2622-1748 (Online), 2684-902X (Print)

DOI: http://dx.doi.org/10.24036/perspektif.v4i4.544

\title{
Dampak Sosial Perubahan Kepemilikan PT Semen Padang ke Semen Indonesia Terhadap Masyarakat di Kelurahan Padang Besi Kecamatan Lubuk Kilangan Kota Padang
}

\author{
Dona Rahmaidil Savitri ${ }^{1}$, Eka Vidya Putra ${ }^{2}$ \\ 1,2Universitas Negeri Padang \\ Email: donarahmaidil@gmail.com, $\underline{\text { ekavidyaputra@gmail.com }}$
}

\begin{abstract}
Abstrak
Penelitian ini bertujuan untuk mengetahui bagaimana dampak sosial perubahan PT Semen Padang ke Semen Indonesia terhadap masyarakat di Kelurahan Padang Besi Kecamatan Lubuk Kilangan Kota Padang. Dari latar belakang terlihat bagaimana masyarakat sebelum terjadi perpindahan banyak masyarakat mendapatkan bantuan dari segi sosial dan ekonomi. Perubahan PT Semen Padang ke Semen Indonesia membuat bantuan yang diberikan oleh Semen Padang berkurang hal tersebut karena masyarakat sangat bergantung terhadap bantuan sosial yang diberikan. Metode penelitian dalam penelitian ini mengunakan metode penelitian kualitatif dengan teknik pengumpulan data berupa observasi, wawancara dan dokumentasi, dengan jumlah informan 15 orang. Teori yang digunakan untuk menganalisis penelitian ini yaitu teori AGIL dari Talcon Parsons. Mengenai perubahan sosial yang sifatnya pada struktur sosial. karena teori ini dirasa mampu untuk dijadikan pisau analisis untuk menganalisis temuan dalam penelitian ini. Lokasi penelitian dilaksanakan di Kelurahan Padang Besi Kecamatan Lubuk Kilangan Kota Padang. Hasil penelitian yang telah dilakukkan di lapangan menemukan bahwa ada beberapa dampak sosial yang pertama berkurangnya bantuan sosial meliputi yaitu bantuan UMKN, Paket Sembako, Pendidikan, perbaikan dan anggaran masjid, selanjutnya ekonomi masyarakat dan tenaga kerja.
\end{abstract}

Kata Kunci: Dampak sosial, Kelurahan Padang Besi, PT Semen Padang

Abstract

This study aims to find out how the social impact of changes from PT Semen Padang to Semen Indonesia on the community in Padang Besi Village, Lubuk Kilangan District, Padang City. From the background, it can be seen how the community before the displacement occurred, many people received social and economic assistance. The change from PT Semen Padang to Semen Indonesia has reduced the assistance provided by Semen Padang because the community is very dependent on the social assistance provided. The research method in this study uses qualitative research methods with data collection techniques in the form of observation, interviews and documentation, with a total of 15 informants. The theory used to analyze this research is the theory of AGIL from Talcon Parsons. Regarding social changes that are in the social structure. because this theory is considered capable of being used as an analytical knife to analyze the findings in this study. The location of the research was carried out in Padang Besi Village, Lubuk Kilangan District, Padang City. The results of research that has been carried out in the field found that there were several social impacts, firstly, reduced social assistance, including UMKN assistance, basic food packages, education, mosque repairs and budgets, then the community economy and labor.

Keywords: PT Semen Padang, Padang Besi Village, Social impact

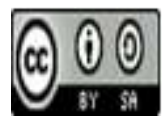

Received: October 11, $2021 \quad$ Revised: December 23, $2021 \quad$ Available Online: December 24, 2021 


\section{Pendahuluan}

Pembagunan merupakan suatu proses yang menunjukkan adanya suatu kegiatan guna mencapai kondisi yang lebih baik dibadingkan dengan kondisi sebelumnya. Perekonomian suatu Negara sangat mempengaruhi kualitas sumber daya manusia. Kesejahteraan masyarakat dapat dilihat dari adanya pembangunan, pembagunan kota merupakan suatu proses berupa perubahan kondisi kota menjadi lebih baik yang berlangsung lama dan terus menerus. Perubahan ini meliputi segala sector yaitu sector jasa, industry dan pertanian (pengolahan hasil pertanian) dan di segi penerimaan masyarakat atau disegi pengeluaran komsumsi, investasi, dan kegiatan pemerintahan daerah serta ekspor-impornya. Selanjutnya diharapkan agar kegiatan perekonomian kota itu membuka kesempatan kerja lebih banyak, sehingga tercapilah kemerataan disegala bidang dalam kehidupan kota. Banyak hal yang mempengaruhi ekonomi suatu kota salah satunya yaitu keberadaan industri.

Salah satu arah pembangunan adalah sektor industry. Sektor industri diyakini mampu menciptakan suatu keadaan perekonomian yang lebih baik lagi bagi kesejahteraan masyarakat secara umum (Rofi, 2012). Strategi pembangunan sektor industrialisasi terbukti telah meningkatkan pertumbuhan ekonomi yang cukup stabil. (Andriani, 2015). Tidak banyak ditemukan sector industri dalam pembangunan di Sumatera Barat. Salah satu yang dapat dijadikan rujukan adalah keberadaan PT Semen Padang.

PT Semen Padang didirikan pada tanggal 18 Maret 1910 merupakan Pabrik semen yang ada di Sumatra Barat. Pada awal berdiri pabrik semen ini diberi nama NV Nederlandsch Indische Portland Cement Maatschappij (NV NIPCM). Setelah Indonesia merdeka, tepatnya pada tanggal 5 Juli 1958 PT Semen Padang dinasionalisasi oleh pemerintah Republik Indonesia dari Pemerintah Belanda. Pada tahun 1995 bersamaan dengan pengembangan Pabrik Indarung V, pemerintah mengalihkan kepemilikan saham PT Semen Padang ke PT Semen Gersik. Kemudian dari tahun 2012, perusahan menjadi bagian dari PT Semen Indonesia. PT Semen Indoensia merupalan BUMN holding, disini bernaung tiga pabrik semen yakni PT Semen Padang bersama PT Semen Gersik dan PT Semen Tonasa.(www.semenpadang.co.id).

Perusahaan mengoperasikan 5 pabrik semen. Kapasitas produksi Semen Padang kurang lebih sebanyak 7,4 ton. Pangsa pasar utama dari Semen Padang adalah Sumatra dan sebagian Jawa sebagian barat. Keberadaan Semen Padang di Kota Padang, Sumatra Barat secara sosial menjadi kebanggan dari masyarakat Sumatra Barat lebih khususnya lagi masyarakat Kecamatan Lubuk Kilangan di Kelurahan Padang Besi. Keberadaan PT Semen Padang bagi masyarakat Lubuk Kilangan di Kelurahan Padang Besi juga berdampak sosial dan ekonomi sejumlah bantuan yang selama ini diberikan oleh PT Semen Padang bantuan UMKM,bantuan Pendidikan, RSTM, paket Sembako, dan lainnya. Tidak hanya itu, keberadaan PT Semen Padang juga banyak membantu pembagunan masyarakat sekitar seperti bantuan Pembagunan Mesjid dan perbaikan rumah masyarakat. Banyaknya bantuan yang diberikan oleh PT Semen Padang kepada masyarakat setempat tidak lepas dari kebijakan perusahaan untuk meningkatkan peran serta mereka dalam memajukan lingkungan sosial.

Dampak pembangunan industri terhadap aspek sosial ekonomi meliputi mata pencaharian penduduk dari sektor pertanian menjadi sektor industri dan perdagangan, dampak lainnya terbukanya kesempatan kerja yang lebih luas baik bagi masyarakat setempat maupun masyarakat pendatang. Dampak Industri terhadap Sosial Ekonomi Dampak adalah suatu perubahan yang disebabkan oleh suatu kegiatan, suatu usaha investasi dalam kegiatan 
pembangunan memilki kemampuan potensial menimbulkan dampak. Konsep dampak diartikan sebagai pengaruh munculnya aktifitas manusia dalam pembangunan terhadap lingkungan termasuk manusia.(nurkolis noviani, 2015). Dalam kebijakan PT Semen Padang membetuk sebuah program tanggung jawab sosial (Corporate Social Responsibility /CSR). Corporate Social Responsibility (CSR) adalah untuk pemberdayaan manusia, karena pemberdayaan tersebut bertujuan untuk mengkreasikan masyarakat mandiri. PT Semen Padang yang terletak dikawasan Kecamatan Lubuk Kilangan, Padang juga memiliki kewajiban yang sama atas hal tersebut. Begitupun dengan masyarakat yang berada di sekitar area perusahaan beroperasi, dalam penelitian ini peneliti mengambil fokus terhadap pemberdayaan anak nagari Kecamatan Lubuk Kilangan yang telah lama tinggal dan menetap di sekitar area perusahaan PT. Semen Padang. PT. Semen Padang menyadari bahwa kesinambungan dan pencapaian kinerja perusahaan salah satunya ditentukan oleh hubungan harmonis antara perusahaan dengan masyarakat dan lingkungan, maka berkaitan dengan hal tersebut.

Selain itu PT. Semen Padang menjabarkan Corporate Social Responsibility (CSR) dalam pilar-pilar diantaranya; pertama, Semen Padang Campin Nagari: mencakup program pemasaran (sertifikasi pekerja kontruksi, produk dan pelayanan yang berkelanjutan), program Litbang dan jaminan kualitas (inovasi produk turunan semen untuk kontruksi), implementasi governance, risk, compliance secara terpadu. Kedua, Semen Padang Pandai Nagari: implementasi Human Capital Master Plan (leadership development program, talent management), mendorong terjalinnya hubungan sosial pekerja dan dialog sosial, memastikan terpenuhinya hak-hak dasar pekerja. Ketiga, Semen Padang Paduli Nagari: lumbung nagari (peningkatan produktifitas peternakan, perikanan, dll), sehat nagari, pengembangan pendidikan keterampilan dan budaya, investasi sosial terhadap pembangunan infrastruktur. Keempat, Semen Padang Elok Nagari: pengendalian emisi, pengendalian limbah cair, pengelolaan limbah padat, penggunaan energi terbarukan dan ramah lingkungan, penggunaan teknologi ramah lingkungan, keragaman hayati dan lingkungan hijau. Dalam menjalankan keempat pilar tersebut Corporate Social Responsibility (CSR)PT. Semen Padang melibatkan konsumen, suplier, pemegang saham, KAN, pemerintahan, LSM, dan para karyawan Corporate Social Responsibility (CSR) PT. Semen Padang dikelola dan dijalankan oleh sebuah departemen yang didalamnya terdapat beberapa divisi, yaitu; Departemen komunikasi dan sarana umum, biro Corporate Social Responsibility (CSR), bidang pemberdayaan pendidikan, kesehatan, sosial, dan lingkungan hidup, bidang pemberdayaan ekonomi, bidang keuangan dan administrasi. Pelaksana Corporate Social Responsibility (CSR) memiliki tanggung jawab penuh untuk menyusun Rencana Jangka Panjang (RJP) dan Rencana Kerja dan Anggaran (RKA), mengatur penyaluran program dan pembinaan, pelaksanaan program dan pembinaan, mengkomunikasikan aktivitas program secara internal dan eksternal, serta melakukan monitoring dan evaluasi terhadap program yang telah dilaksanakan (www.semenpadang.co.id).

Melalui program CSR, observasi awal manfaat dari keberadaan PT Semen Padang adanya ketergantungan masyarakat dengan bantuan yang diberikan oleh PT Semen Padang. bentuk bantuan yang diberikan oleh PT Semen Padang kepada masyarakat berupa bantuan UMKM seperti memberikan bantuan modal usaha ke pedangang bakso berupa gerobak, etalase bagi warung-warung kecil dan diberikan kulkas. Selain bantuan UMKM juga ada bantuan pendidikan yang diberikan oleh PT. Semen Padang berupa bantuan beasiswa untuk pendidikan, disamping itu juga diberikan bantuan sosial berupa beras untuk masyarakat miskin. Namun semenjak beralihnya PT. Semen Padang ke Semen Indonesia bantuan yang 
Dona Rahmaidil Savitri, Eka Vidya Putra Dampak Sosial Perubahan Kepemilikan PT Semen Padang ke Semen Indonesia di Kelurahan Padang Besi Kecamatan Lubuk Kilangan Kota Padang

diberikan sebelumnya berkurang. Berikut data batuan dari PT Semen Padang yang dialokasikan ke masyarakat.

Peralihan kepemilikan PT Semen Padang ke Semen Indonesia jumlah bantuan yang diperoleh oleh masyarakat jauh berkurang. Berdasarkan observasi yang dilakukan penyebab berkurangnya jumlah bantuan tersebut adalah kantor PT Semen Padang yang ada di Indarung lebih pada pengurusan administrasi tidak lagi kebijakan. Sehingga bantuan-bantuan yang diberikan menjadi berkurang. Bantuan yang rutin diberikan hingga saat ini hanya bantuan UMKM dan beasiswa. Berkurangnya bantuan tersebut tentu memiliki dampak sosial bagi masyarakat, khususnya yang berada di sekitar PT Semen Padang. Menarik untuk melihat lebih jauh bagaimana dampak sosial dari berkurangnya bantuan tersebut kepada masyarakat terhadap masyarakat di Kelurahan Padang Besi Kecamatan Lubuk Kilangan Kota Padang.

Berangkat dari permasalahan tersebut maka tujuan penelitian ini adalah bagaimana dampak perubahan kepemilikan PT Semen Padang ke Semen Indonesia terhadap masyarakat Penelitian ini diharapkan dapat menambah cakrawala serta wawasan masyarakat ilmiah mengenai Peralihan kepemilikan PT Semen Padang ke Semen Indonesia. Sejumlah penelitian yang dilakukan Oleh Imam Nawawi tentang "Pengaruh Keberadaan Industri terhadap Kondisi Sosial Ekonomi dan Budaya Masyarakat". Dampak yang ditimbulkan dari segi ekonomi masyarakat berubahnya mata pencarian dan daya serap tenaga kerja. Adanya pembagunan industri masyarakat akan tergerus dan berubah sehingga masyarakat yag sudah tua dan tidak produktif bekerja serta tidak tersaing oleh adanya industri mengalami kerugian dan kehilangan mata pencarian, sehingga akan berdampak negative dan berkurangya pedapatan. pada dasarnya pembagunan ini menambah pendapatan asli daerah maupun meningkatkan kesejahteraan masyarakat, tetapi sebalikya menciptakan pencemaran dan marginalisasi masyarakat lokal.

Studi relevan selajutnya tentang "Dampak keberadaan industri terhadap kondisi sosial ekonomi masyarakat serta lingkungan Sekitar Industri”. Oleh Nurkolis (2015). dampak dari keberadaan industri ini perubahan dari segi mata pencarian masyarakat yang semula bertani dan menjadi pekerja industri di tempat pembagunan industri dan sosial budaya berkurangnya kekuatan nilai sosial dan norma budaya yang baru yang di bawa oleh masyarakat pendatang atau imigran berubah akibat dari pembagunan industri ini yang banyak masyarakat terkena dampak dari pembagunan industri ini.

Studi relevan selanjunya tentang "persepsi masyarakat terhadap dampak aktivitas PT Semen Padang di Kelurahan Padang Besi Kecamatan Lubuk Kilangan. Oleh Rina sulasti, Dedi Hermon, Erna juita. Hasil penelitian ini menunjukkan bagaimana dampak lingkungan bagi aktifitas pabrik ini bagi kesehatan masyarakat buruk terhadap kualitas udara yang masyarakat hirup dan telah membuat kebersihan tempat tinggal masyarakat tergangu dengan abu yang turun ke jalan dan akibat kabut asap yang dikeluarkan oleh pabrik dapat mengganngu kesehatan yang lokasi pabrik dekat dengan aktivitas masyarakat sehari-hari dan berdampak bagi tatanan sosial masyarakat.

Berangkat dari pemaparan pendahuluan dan literatur review di atas, jika dilihat dari objek kajian memiliki kesamaan yaitu mengenai dampak dan pengaruh keberadaan industri, hanya saja jika beberapa penelitian terdahulu berfokus pada dampak social terhadap perubahan industry maka pada artikel ini peneliti fokus pada dampak social perubahan kepemilikan industry. Dengan demikian kebaruan dalam penelitian ini mendeskripsikan realita mengenai bagaimana dampak social perubahan industry perspektif Talcon Parson. Adapun pertanyaan penelitian yang ingin dijawab yaitu dampak social perubahan kepemilikan industri. 


\section{Metode Penelitian}

Jenis penelitian yang dipakai dalam penelitian ini adalah Penelitian Deskriptif Kualitatif. Sebagaimana telah disebutkan dalam perumusan masalah dan tujuan penelitian. Penelitian ini bertujuan untuk mencari atau menggali sumber-sumber data dan informasi berkaitan dengan permasalahan penelitian, mengenai dampak sosial perubahan kepemilikan PT Semen Padang ke Semen Indonesia di Kelurahan Padang Besi Kecamatan Lubuk Kilangan Kota Padang. Dalam penelitian dengan pendekatan kualitatif, menurut. (Sugiyono, 2012) bertujuan untuk mengungkapkan informasi kualitatif sehingga lebih menekankan pada masalah proses dan makna dengan mendeskripsikan sesuatu masalah.

Sedangkan tipe penelitian kualitatif deskriptif adalah berupa penelitian dengan metode atau pendekatan studi kasus (Case Study). Studi kasus termasuk dalam penelitian analisis deskriptif, yaitu penelitian yang dilakukan terfokus pada suatu kasus tertentu untuk diamati dan dianalisis secara cermat sampai tuntas. Kasus yang dimaksud bisa berupa tunggal atau jamak, misalnya berupa individu atau organisasi. Di sini perlu dilakukan analisis secara tajam terhadap berbagai faktor yang terkait dengan kasus tersebut sehingga akhirnya akan diperoleh kesimpulan yang akurat.(Sutedi, 2009) Tipe penelitian studi kasus dalam penelitian ini, berupa kasus yag terjadi di masyarakat yang berada di Kelurahan Padang Besi Kecamatan Lubuk Kilangan Kota Padang, mengenai bagaimana dampak perubahan kepemilikan PT Semen Padang ke Semen Indonesia, dengan jumlah informan 15 orang.

Teknik pengumpulan data dilakukan dengan tiga cara yaitu oebservasi non partisipan, dalam penelitian ini peneliti hanya sebagai pengamat, agar mendapatkan secara langsug gambara mengenai dampak sosial peralihan PT Semen Padang ke PT Semen Indonesia. Adapun proses dan analisis data menurut Miles dan Huberman, bahwa ada tiga alur kegiatan, yaitu reduksi data, penyajian data, serta penarikan kesimpulan atau verifikasi. Pengumpulan data pada penelitian kualiatif instrumen utamanya adalah peneliti sendiri (human instrumen), untuk mencari data dengan berinteraksi secara simbolik dengan informan/subyek yang diteliti. Proses triangulasi yang peneliti lakukan yaitu triangulasi metode dilakukan dengan membandingkan hasil wawancara, observasi dan dokumentasi. Apabila data ketiga teknik pengumpulan data tersebut menghasilkan data yang berbeda, maka penulis melakukan diskusi lebih lanjut kepada informan yang bersangkutan untuk memperoleh data yang dianggap benar (Sugiyono, 2012). Reduksi data dilakukan sejak pengumpulan data, dimulai dengan membuat ringkasan, mengkode, menelusuri tema, menulis memo, dan lain sebagainya. Proses reduksi data ini peneliti lakukan dengan memisahkan pernyataan informan yang relevan dengan data yang peneliti perlukan, dan mana yang tidak diperlukan. Hal ini dilakukan untuk mempermudah peneliti melakukan pengumpulan data selajutnya dan mencarinya bila diperlukan. Pernyataan dari informan penulis catat setelah itu baru penulis pisahkan mana data yang relevan mana data yan tidak relevan dengan penelitian ini.

Proses reduksi data mempermudah peneliti dalam melakukan pengumpulan data selanjutnya. Penyajian data adalah pendeskripsian sekumpulan informasi tersusun yang memberikan kemungkinan adanya penarikan kesimpulan dan pengambilan tindakan. Penyajian data kualitatif disajikan dalam bentuk teks naratif dengan tujuan dirancang untuk menggabungkan informasi yang padu. Data dalam penelitian ini disajikan dalam bentuk tabel dan tulisan agar mempermudah peneliti dalam melakukan penarikan kesimpulan dan melakukan analisis data yang telah disimpulkan ada tahap reduksi data agar diperoleh data yang akurat (Lexy J. Moeleong: 2019: 50-51). Dalam proses penyajian data peneliti melakukan yang pertama memahami jawaban dari informan, kemudian peneliti 
megelompokkan data tersebut sesuai dengan topik penelitian ini, lalu setelah peneliti memahami jawaban tersebut peneliti sajikan dalam bentuk paragraf dan tabel untuk memudahkan peneliti dalam mengelompokkan data.

\section{Hasil dan Pembahasan}

Penelitian ini melalui pengamatan langsung yang dilakukan oleh peneliti sendiri, Tipe Penelitian ini yaitu studi kasus tepatnya berada di Kelurahan Padang Besi Kecamatan Lubuk Kilangan Kota Padang. Penelitian ini mengkaji terkait dengan dampak sosial perubahan kepemilikan PT Semen Padang ke Semen Indonesia di Kelurahan Padang Besi Kecamatan Lubuk Kilangan Kota Padang, melalui tipe penelitian studi kasus peneliti mendalami dampak sosial perubahan kepemilikan PT Semen Padang ke Semen Indonesia. Proses triangulasi yang peneliti lakukan yaitu triangulasi metode dilakukan dengan membandingkan hasil wawancara, observasi dan dokumentasi. Apabila data ketiga teknik pengumpulan data tersebut menghasilkan data yang berbeda, maka peneliti melakukan diskusi lebih lanjut kepada informan yang bersangkutan untuk memperoleh data yang dianggap benar (Sugiyono, 2012). Teori yang peneliti gunakan untuk menganalisis temuan dalam penelitian ini adalah Teori AGILyang dikemukakan oleh Talcon Parsons untuk mengkaji atau menganalisis permasalahan mengenai dampak sosial perubahan kepemilikan PT Semen Padang ke Semen Indonesia. Toeri ini digunakan dalam penelitian ini adalah teori fungsionalisme (AGIL) menurut Talcon Parson. Merupakan pengikut aliran fungsional yang paling popular. Talcon Parson juga pernah ada menikiran sebagai ahli biologi, banyak berpengaruh dengan rumusan teori fungsional. Bagaimana, masyarakat manusia tak ubahnya seperti organ tubuh manusia, dan oleh karena itu masyarakat manusia dapat juga dipelajari seperti mempelajari tubuh manusia. Pandangan Parsons mengenai perubahan sosial, pada awalnya difokuskan pada sifat struktur sosial yang mengarah pada proses evolusi sosial. Menurut Parsons, studi mengenai perubahan sosial harus dimulai dengan studi mengenai struktur sosial terlebih dahulu. Struktur sosial dapat didefenisikan sebagai tatanan atau susunan sosial yag membentuk kelompok-kelompok sosial dalam masyarakat yang dapat tersusun maupun horizontal atau dapat juga didefenisikan sebagai cara bagaimana suatu masyarakat terorganisasi dalam hubungan-hubungan yang dapat didefenisikan melalui pola perilaku berulang antar individu dan antar kelompok dalam masyarakat tersebut. Secara spesifik, pandangan Parsons mengacu pada diamika yang terjadi dalam system sosial sebagian dalam struktur sosial. Sistem sosial menurut Parsons terdiri atas sejumlah actor individual yang saling berinteraksi dalam situasi yang sekurang-kurangnya mempuyai aspek lingkungan atau fisik, actor-aktor yang memiliki motivasi, dalam arti memiliki kecendrungan untuk mengoptimalkan kepuasan yang berlangsung dengan situasi yag didefenisikan dan dimediasi dalam symbol bersama yag terstruktur secara kultur. Ada empat fungsi penting mutlak dibutuhkan bagi semua system yaitu adaptation atau adaptasi, goal attaimet atau pencapaian tujuan integratio atau integrasi, dan latency pettern maiteace atau pemeliharaa pola-pola late. Keempat fugsi tersebut meurut parsos merupaka fugsi imperative atau prasyarat berlangsung system sosial. Ada fungsifungsi atau kebutuhan-kebutuhn tertentu yang harus dipenuhi oleh setiap system yang hidup. Dua pokok penting yang termasuk ke dalam kebutuhan fungsinal ini adalalah, pertama yag berhubunga denga kebutuhan system interal atau kebutuhan dengan system ini ketika berhubungan dengan lingkungan. Kedua, yag berhubunga denga system sasaran atau tujuan serta saran yang perlu untuk mecapai tersebut. 
Pertama adaptation fungsi ini merupakan yang sangat penting. Pada fungsi ini, system harus dapat beradaptasi denga cara menangulagi situasi eksternal yang kompleks, dan system harus dapat menyesuaikan diri denga lingkunga serta dapat menyesuaikan lingkunga degan kebutuhan. Kedua, goal attaiment. Fungsi ini sangat penting, yaitu system harus dapat mendefenisikan dan mencapai tujuan utama. Fungsi ini merupakan fuvgsi pribadi. Ketiga, integration. Sebuah system harus mampu mengatur dan menjaga hubungan bagian-bagian yang menjadi komponenya. Selain itu, system harus dapat mengatur dan mengelola ketiga fungsi (AGI); fungsi integrasi merupakan fungsi system sosial. Keempat, latent patten maintenance. Sistem harus memelihara dan memperbaiki motivasi pola-pola idividu da kultur.

Teori yang digunakn untuk penelitian ini adalah teori fungsioalisme (AGIL) menrut Talcont Parson. Dinama suatu system yang memilki fungsi akan mengalami suatu perubahan. Dari perubahan tersebut komponen didalam system tersebut harus dapat menyesuaikan degan perubahan yang dilakukan. Komponen yaitu masyarakat baik individu maupun kelompok. Perubahan yang dilihat yaitu tanggapan individu dalam system sosial. Dengan adanya perubahan system akan berdampak terhadap individu atau masyarakat yang ada. Denga adanya kebijakan dalam system perubahan struktur dalam PT Semen Padang yang berubah diatur oleh Semen Indonesia, maka semua system akan berubah dan komponen didalamya juga harus mengikuti perubahan tersebut. Dengan adaya perubahan maka masyarakat sangat berdampak akibat perubahan tersebut. Yang semula sebelum terjadi perpidahan kepemilikan PT Semen Padang ke Semen Indonesia masyarakat sangat bergantung terhadap pabrik industri semen ini karena masyarakat sekitar memiliki dampak masyarakat yaitu masyarakat banyak mendapatkan bantuan-bantuan sosial dan ekonomi dari PT Semen Padang tetapi karena perubahan kepemilikan bantuan itu sangatlah berkurang karena system yang sudah berubah.

\section{Berkurangnya Bantuan Sosial}

Di Kelurahan Padang Besi Kecamatan Lubuk Kilangan akibat dari perpindahan PT Semen Padang ke Semen Indonesia mengakibatkan sejumlah bantuan yang di berikan oleh PT Semen Padang ke masyarakat jauh berkurang seperti bantuan UMKM, Pendidikan, RSTM, Sembako, Pembagunan Mesjid, Perbaikan rumah masyarakat dan lainnya yang sekarang jauh berkurang beberapa bantuan ada beberapa bantuan.

\section{UMKM}

Bantuan UMKM yang di berikan oleh PT Semen Padang ke masyarakat sebelum perpindahan PT Semen Padang ke Semen Indonesia berupa peralatan dan sejumlah modal usaha untuk berdagang. yang dulu masyarakat memasukkan sejumlah prosedur untuk pengurusan agar mendapatkan sejumlah modal usaha agar bisa berdagang yang dulunya mendapatkan seperti modal usaha berupa gerobak untuk berdagang dan peralatan seperti kompor, wajan, dan peralatan untuk berjualan dan modal usaha uang untuk modal awal.

Sekarang ini syarat yang terlalu sulit dan juga dana pengurangan bantuan. Kriteria dalam mendapatkan bantuan modal UMKM masyarakat yang berdagang dan merincikan sejumlah keperluan untuk berdagang dan proposal apa saja yang butuh dalam modal untuk berjualan maka dari itu pihak dari Semen Padang yaitu CSR Semen Padang akan menyeleksi dan mensurvei dalam untuk mendapat bantuan tersebut. Berkurangnya kuantitas masyarakat yang mendapatkan bantuan UMKM dari Semen Indonesia dapat dilihat dari perbandingan masyarakat yang mendapatkan bantuan pada tahun 2010 anggarannya sebesar $6,7 \mathrm{M}$ pada saat 
PT Semen Padang sedangkan pada tahun 2018 anggarannya 6,7M setelah diambil alih oleh PT Semen Indonesia (www.semenpadang.co.id)

Manfaat dari bantuan tersebut agar bisa mendorong perekomonian masyarakat dalam berjualan dan modal usaha, dari sebelum perpindahan PT Semen Padang ini banyak masyarakat sekitar yang mendapat bantuan dari PT Semen Padang akan tetapi setelah terjadi perpindahan ini masyarakat sulit dengan prosedur yang diberikan oleh PT Semen Indonesia yang dalam pengurusan berbelit-belit hingga setiap tahun berkurang masyarakat yang mendapatkan bantuan tersebut. Akibat dari perpindahan ini menjadi sulit dalam bantuan yang diberikan oleh Semen Padang

Hal tersebut sesuai dengan pernyataan informan RS (36 th) sebagai berikut:

“...Kalau untuk sekarang serba susah yang mau di urus ke semen dan saya kemaren mengurus agar mendapat bantuan berdangang sekarang ini prosedurnya terlalu rumit dan berbelit-belit dan pada akhirnya tidak dapat dan sudah setahun saya urus tidak kunjung dapat" (Wawancara tanggal 27 September 2021).

Hal tersebut juga sama disampaikan WA (44 th), sebagai berikut:

"...Iya nak ibuk sekarang sudah kedua kali mengurus tapi sekarang tidak mendapatkan dulu pernah dapat proses yang cepat sekarang urus nya ribet setelah semen padang berubah (Wawancara tanggal 27 September 2021).

Hal yang sama juga di sampaikan GA (49 th) sebagai berikut:

“...Pada zaman sekarang ini untuk mencari modal usaha ibuk bantuan modal usaha ibuk kemaren masukkan proposal untuk berjualan dan iyya prosedur sekarang sudah banyak dan tidak seperti dulu lagi yang pernah anak ibuk mengurus ke semen padang tapi sekarang tidak dapat bantuan umkm dari semen padang" (Wawancara tanggal 27 September 2021).

Berdasarkan observasi peneliti dapatkan dari wawancara di atas dapat di simpulkan dan di ketahui semenjak terjadi perubahan dan peralihan PT Semen Padang ke Semen Indonesia masyarakat sangat berdampak pada dalam segi bantuan UMKM yang di dapatkan sejumlah bantuan yang berkurang dan bahkan prosedur yang terlalu rumit dalam proses yang di dapatkan hingga masyarakat yang dulu sering mendapatkan bantuan sekarang ada yang tidak mendapatkan bantuan itu tersebut.

\section{Pendidikan}

Bantuan beasiswa pendidikan emang beberapa tahun belakangan ini CSR Semen Padang memberikan bantuan pendidikan kepada siswa-siswa di Kota Padang khususnnya masyarakat di Kelurahan Padang Besi bantuan beasiswa ini untuk siswa yang berprestasi yang memiliki nilai dalam nilai rapor mendapatkan rangking 10 besar dalam sekolah dan siswa yang berprestasi tapi siswa kurang mampu dalam sekolah dalam pengurusan beasiswa ini mendapatkan uang sebesar untuk SD 400.000 dan SMP 500.00 dan SMA 750.00 dan Perguruan Tinggi sebesar 1.000.000 dalam mendapatkan beasiswa ini agar masyarakat yang anaknya berprestasi di sekitar Kecamatan Lubuk Kilangan ini mendapat beasiswa tapi semenjak beberapa tahun belakangan ini jumalahnya berkurang. PT Semen Indonesia menyalurkan bantuan pendidikan pada tahun 2016 sebanyak 1.342 siswa, pada tahun 2017 sebanyak 1.048 siswa dan 2019 sebanyak 693 siswa dalam setiap tahun. Pada tahun 2010 (PT 
Semen Padang) bantuan pendidikan yang disalurkan berjumlah 3. 373 siswa. Dapat dilihat selisih jumlah siswa yang mendapatkan bantuan pendidikan dari peralihan PT Semen Padang ke PT Semen Indonesia (www.semenpadang.co.id).

Siswa mendapatkan bantuan dari data yang didapatkan terjadi sejumlah pengurangan yang signifikan. Hal ini juga dipengaruhi oleh prosedur yang panjang seharusnya perpindahan pengelolaan ini justru semakin maju bukan semakin terjadi pengurangan.

Hal tersebut juga di sampaikan AW (15 th) sebagai berikut:

“...Ya kak saya dari SD sudah mendapatkan beasiswa dari semen padang tapi pas saya smp saya tidak mendapatkan katanya sudah tidak dapat lagi saya juga tidak tau kenapa saya tidak dapat biasanya saya dapat beasiswa karena untuk uang belanja sekolah" (Wawancara Tanggal 30 Oktober 2021).

Hal tersebut juga di sampaikan AN (40 th) sebagai berikut:

“...Anak saya mengurus dulu pas smp dia dapat beasiswa dari semen padang saya urus dulu ke semen padang syaratnya mudah dan sekarang tidak dapat karena semua prosedur yang urus oleh semen Indonesia pernah saya bertanya kenapa tidak dapat karena ada pengurangan dan semua prosedur di urus oleh semen Indonesia" (Wawancara Tanggal 30 September 2021)

Dari pernyataan informan yang di dapatkan bahwa beasiswa yang biasanya di kucurkan tetapi dua tahun belakangan ini tidak mendapatkan bahwa terjadi pengurangan siswa yang mendapatkan batuan beasiswa. Seharusnya pada dengan di kelolanya semen yang merupakan penunjang untuk masyarakat yang anaknya bersekolah agar bisa PT Semen Padang membantu bagaimana pendidikan maju di sekitar Kecamatan Lubuk Kilangan tetapi dengan perpindahan PT Semen Padang ini terjadi nya perubahan Kelola yang sekarang ini mengatur dalam segi bantuan beasiswa ini Semen Indonesia maka terjadinya pengurangan yang mendapatkan bantuan beasiswa pendidikan.

\section{Paket Sembako}

Paket sembako merupakan salah penunjang perekomian masyarakat yang di dapatkan oleh PT Semen Padang yang di berikan kepada masyarakat di Kecamatan Lubuk Kilangan. Paket sembako yang di berikan oleh Semen Padang ini dahulu nya banyak memberikan kepada masyarakat dengan kriteria masyarakat kurang mampu dan biasanya ada di bagikan salah satu gedung di PT Semen Padang berjejer paket sembako yang biasanya masyarakat bisa mendapatkan sembako yang murah seperti beras,minyak,gula,tepung,sabun cuci dan peralatan rumah tangga lainnya dan melalui RT masing-masing pembagian kupon 10 per KK masing-masing masyarakat yang mendapatkan bantuan ini.apalagi dengan tahun sekarang ini adanya musibah yaitu COVID-19 dengan produksi PT Semen Padang berkurang maka merambat semua pada keuangan Semen Padang yang berdampak pada bantuan yang di berikan oleh PT Semen Padang ke masyarakat. Dan juga dengan perpindahan Semen Padang ini masyarakat mengeluh tidak mendapatkan bantuan ini. karena terjadinya peralihan kepemilikan PT Semen Padang ke Semen Indonesia yang dampak sosial bagi masyarakat sekitar yang tidak adanya paket sembako murah yang dulunya di laksanakan setiap tahun oleh Semen Padang yang kini karena peralihan ke Semen Indonesia pada tahun 2008 anggaran untuk bantuan sembako yang disalurkan kepada masyarakat dari PT Semen Padang 
berjumlah 3M, sedangkan pada tahun 2020 yang saat ini telah dinaungi oleh PT Semen Indonesia yaitu 1,1M (www.semenpadang.co.id).

Hal tersebut juga di sampaikan oleh RA (45 th) sebagai berikut:

“...Saya sebagai rt setempat disini sudah lama tidak dapat kupon bantuan sembako murah dari semen padang biasa warga saya dapat kupon tapi sekarang sudah berapa tahun tidak mendapatkan lagi sembako murah yang biasa dulu mendapatkan" (Wawancara Tanggal 2 Oktober 2021)

Hal tersebut juga di sampaikan oleh TT (44 th) sebagai berikut:

"Iya nak ibuk dulu pernah dapat paket sembako murah kupon di bagikan sama rt setempat untuk bisa menambah keperluan di rumah dan biasa dapat beras, gula dan yang lainnya tapi sudah berapa tahun tidak mendapatkannya lagi" (Wawancara Tanggal 2 Oktober 2021).

Berdasarkan observasi dan wawancara di atas terhadap informan bahwa paket sembako yang diberikan oleh PT Semen Padang mengalami pengurangan dan beberapa tahun terakhir tidak berikan lagi. Dan juga dana bantuan yang dulu nya itu disalukan kepada bantuan maka ada yang tidak dapat lagi. Dan akibat pendemi COVID-19 memeng semua bidang industry sangatlah berdampak terhadap perekonomian sekarang ini dan dalam proses ini mengakibatkan produksi PT Semen Padang mengalami tersendat.

\section{Perbaikan dan anggaran Mesjid}

Dalam anggaran PT Semen Padang memang setiap tahun mendapat bantuan seperti anak yatim, perbaikan masjid dan infaq qurban setiap tahun di berikan oleh Semen Padang tetapi di Kelurahan Padang besi salah satu mesjid yang ada jatah setiap tahun mendapat anggaran melalui Semen Padang yang pada tahun 2016 mendapat 25.000.000 Juta bantuan perbaikan Atap mesjid, 2017 ada 15. 000.0000 juta dan 2018 yaitu 10.000 .000 juta untuk anak yatim dan TPA/TPQ mesjid dan sudah tiga tahun anggaran itu tidak dapat lagi karena pengurusan yang sulit dan pengurangan jumlah yang didapatkan tidak seperti dahulu karena pengelolaan ini di lakukan dan di seleksi oleh Semen Indonesia maka dari itu sudah tidak dapat lagi. Pada saat PT Semen Padang pembangunan untuk masjid yang berada di lubuk kilangan dibantu pembangunannya dengan tahap I dan II sebesar Rp.457 juta, rinciannya pada tahap I Rp. 187 juta, dan pada tahap II Rp. 270 juta. Dari perbandingan jumlah anggaran yang disalurkan bisa dilihat adanya pengurangan dari awalnya PT Semen Padang ke PT Semen Indonesia (www.semenpadang.co.id).

Hal tersebut juga di sampaikan oleh RM (35 th) sebagai berikut:

“... Saya selaku pengurus mesjid memang sudah beberapa tahun belakangan tidak dapat bantuan dan itu menjadi kendala dalam dana mesjid yang biasanya mendapat bantuan dana dari Semen Padang tapi beberapa tahun belakangan ini tidak dapat karena itu sudah pengurusan yang berbeda dan sudah atur oleh Semen Indonesia" (Wawancara Tanggal 4 Oktober 2021)

Hal yang sama juga di sampaikan oleh MA (60 th) sebagai berikut:

“...Sekarang sudah dilihat anggaran mesjid kosong karena tidak ada dapat bantuan sama Semen Padang dan saya Nampak tidak ada kemajuan mesjid tapi iyya ada uang infaq mesjid tapi itu tidak cukup untuk pembagunan mesjid dan 
berharap ada dapat bantuan uang dari Semen Padang” (Wawancara Tanggal 4 Oktober 2021)

Dari hasil wawancaran dan observasi peneliti dapat simpulkan bahwa tidak ada bantuan mesjid yang diberikan oleh Semen Padang yang setiap tahun mendapatkan tapi sekarang tidak ada lagi maka dari itu terjadi kendala pada pembagunan mesjid yang biasa dana tersebut di dapatkan oleh Semen Padang.

\section{Ekonomi Masyarakat}

Dalam penunjang industrilisasi juga mengakibatkan di lingkungan sekitar mengalami perubahan atau berdampak terhadap ekonomi masyarakat. Seperti rumah kost-kost yang dapat menunjang pendapatan masyarakat, dimana karyawan PT Semen Padang yang bekerja tidak memiliki rumah pribadi mereka bisa kost atau mengontrak rumah yang dimiliki oleh masyarakat asli lubuk kilangan namun saat ini karena tenaga kerja adanya pengurangan jadi pendapatan masyarakat yang sumber pendapatannya dari penyewaan kost atau mengontrakan rumah menurun. Sehingga selama ia bekeja di Pabrik PT Semen Padang ia menempati runah yaitu kost-kost an menyewa dengan adanya PT Semen Padang ini dapat meningkatkan ekonomi masyarakat, tetapi dengan yang di alami beberapa tahun belakangan ini di akui oleh warga setempat yang juragan kost-kost mengalami pengurangan omset per bulan nya karena banyaknya rumah kost-kost ini tidak adalagi penghuni dan kosong di karenakan dengan pemindahan PT Semen Padang ke Semen Indonesia yang mengakibatkan berkuranganya karyawan yang biasanya ramai dari berbagai daerah seperti Jambi, Palembang, Medan, Jakarta, Bukitinggi, Pasaman dan daerah lainnya yang merantau untuk bekerja di PT Semen Padang.

Dengan adanya perubahan tidak ada perekrutan karyawanan maka dari itu terjadi penghuni kost-kost an tidak ada yang duluya penuh dan susah untuk mencari rumah kost-kost karena semua sudah diisi oleh karyawan PT Semen Padang yang ia merantau untuk bekerja di PT Semen Padang di perkirakan dahulu omset masyarakat yang memilki rumah kost-kost an pertahun bisa 40 juta pertahun yang memiliki 6 pintu rumah kost-kost an tetapi sekarang apalagi tidak adanya karyawan tinggal di kost-kos an yang paling bisa sekarang 3 pintu lumayan terisi yang biasanya penuh tetapi sekarang berkurang akibat tidak adanya karyawan PT Semen Padang yang tinggal di rumah kost-kos an.

Dan juga pedangang kaki lima yang berjualan di sekitar jalan raya dekat Pabrik PT Semen Padang mengalami dampak ekonomi karena penjualan yang berkurang dikarenakan tidak ada lagi yang biasa makan siang banyak disini sopir truk dan karyawan Semen Padang yang makan siang disini berkurang itu tidak sebanyak dahulu yang ramai biasanya dalam sehari bisa mendapatkan 1,5 juta lebih kurang tetapi pada masa peralihan ini 500 ribu aja untung mendapatkan karena. Yang dahulu masyarakat yang berjualan memiliki anak buah sekarang mengalami pengurangan karena tidaksebanding antara pemasukan dengan penguranan maka karyawan di warung di kurangkan yang semula ada tukang masak, cuci piring dan pelayan sekiata karyawan di warung ada 6 orang karyawan sekarang di perkecil menjadi satu pelayan, satu cuci piring, satu memasak dan satu kasir. Dengan peralihan ini ke Semen Indonesia karyawan yang belanja sedikit karena pendapatkan mereka berkurang sehingga ia berhemat dan tidak makan disini dan juga karyawan yang makan disini mengeluh pada pekerjaan yang gaji nya berkurang akibat semua mengatur oleh Semen Indonesia yang 
gaji tidak sebesar dulu jadi ia untuk pengeluaran berhemat maka disekitar warung-warung di sekitar pabrik mengakibatkan sepi pengunjung yang dahulu rame pembeli yang kebanyakan karyawan PT Semen Padang makan siang di warung dekat pabrik.

Hal tersebut juga di sampaikan oleh TN (45 th) sebagai berikut:

“... Sekarang ini adik sudah banyak ada beberapa pintu kost-kost an yang kosong biasanya disini semua anak daerah yang tingga disini karena karyawan yang bekerja di Semen Padang dengan tidak ada perekrutan karyawan maka tidak ada yang berhunyi rumah kost-kost an sekarang" (Wawancara Tanggal 5 Oktober 2021)

\section{Tenaga Kerja}

Salah Penunjang dalam pabrik industry salah satunya dengan tenaga kerja yang banyak Karena dalam proses industry tenaga kerja justru banyak di butuhkan agar pendapatan dan hasil dalam produksi berjalan dengan lancar yang berkerja banyak masyarakat Kota Padang . Akan tetapi dengan perluasan wilayah dan kepemiliki saham juga berkibat dalam beberapa hal yang justru ada baik dan buruknya dengan adanya perubahan ini PT Semen Padang berpindahan dan perluasan saham menjadi PT Semen Indonesia berakibat pada tenaga kerja yang semakin berkurang tenaga kerja. Dalam hal ini ada bernaung Forum Anak Nagari yang di kelola anak nagari di Kecamatan Lubuk kilangan Kelurahan Padang besi sebuah forum yang lokasi Pabrik industry Semen Padang ini juga memberi manfaat di berbagai sector seperti perekrutan karyawan bagi anak nagari yang tinggal dekat. Yang anak nagari PT Semen Padang bekerja dapat berkerja sebagai Buruh, Clening Servis, Pekerja Pabrik, Penyapu Jalan dan pekerjaan yang lainnya.

Ada perjanjian bahwa memang ketika ada lowongan di buka setengah dari penerimaan karyawan ada anak nagari yang bekeja di PT Semen Padang karena dalam perjanjian ada akan tetapi dengan perubahan system kepemilikan dan ini menjadi Semen Indonesia perekrutan karyawan anak nagari tidak ada lagi. yang biasa ada pelatihan dan segala macam sekarang di kurangnya dan sekarang system yang dikirim dari Jakarta pusat dari Semen Indonesia dan juga peraturan dalam penerimaan karyawan yang rumit memiliki beberapa syarat agar bisa menjadi karyawan PT Semen Padang akan tetapi justru tidak hal anak nagari cepat harus dapet kerja tapi forum nagari mampu memenuhi syarat tersebut seperti yang tamatan dan berpengalam pada bidang yang akan ia bekerja. Kondisi ini membuat beberapa kali terjadi demo massa anak nagari yang berdemo ke Semen Padang karena sudah ada perjanjian dan tanah hulayat yang Pabrik Semen Padang ada di lokasi masyarakat tinggal maka dari itu masyarakat kecewa terhadap system yang sekarang tidak ada perekrutan karyawan bagi anak nagari yang bekeja di PT Semen Padang. Karyawan PT Semen Padang terdiri dari karyawan tetap dan tidak tetap. Pada tahun 2014 total karyawan PT Semen Padang sebanyak 1924 orang dari totaltersebut 32 orang merupakan karyawan tidak tetap. Tahun 2015 jumlah karyawan PT Semen Padang adalah 1856 orang dengan jumlah karyawan tidak tetap sebanyak 49 orang. Dari data tersebut dapat dilihat bahwa terjadi penurunan karyawan pada tahun 2015 sebanyak 75 orang. Pada tahun 2016 jumlah karyawan PT Semen Padang terus mengalami penurunan. Total jumlah karyawan PT Semen Padang pada tahun 2016 berjumlah 1730 orang. (handoko suryo,putri nilda, 2017)

Hal tersebut juga di sampaikan oleh AG (55 th) sebagai berikut: 
“...Sebagai anak nagari disini masuk kerja ke Semen Padang sekarang sudah tidak bisa dapat kerja tidak adanya lowongan dan memang ada perjanjian dari anak nagari setiap ada penerimaan karyawan tapi sekarang pas di mintak hak untuk ada anak nagari yang bekeja di Semen Padang tidak ada karena yang mengurus semua oleh Semen Indonesia” (Wawancara Tanggal 5 Oktober 2021).

Hal tersebut juga di sampaikan oleh PR (40 th) sebagai berikut:

“...Kalau saya disini tamatan SMA tentu berharap kerja dipabrik semen apalagi pabrik sudah lama dan dekat. Bisa saya bekerja disini tetapi tidak bisa kerja karena karena kebanyakan orang luar nampak dengan saya dengan nantik ketika ada lowongan bisa anak nagari yang bekerja" (Wawancara Tanggal 5 Oktober 2021).

\section{Kesimpulan}

Adapun dampak sosial perubahan kepemilikan PT Semen Padang ke Semen Indonesia terhadap masyarakat membuat bantuan sosial berkurang akibat peralihan ini, yang semula duhulu pabrik PT Semen Padang banyak memberikan bantuan kepada masyarakat di sekitar pabrik memberikan bantuan seperti, bantuan Sembako, UMKM, Pendidikan, dan Anggaran Mesjid, dan dalam segi ekonomi masyarakat yang berjualan dekat pabrik ekonomi sangat berkurang karena perpindahan PT Semen Padang ke Semen Indonesia dan juga dalam segi tenaga kerja tidak ada perekrutan karyawan setelah terjadi perpindahan ke Semen Indonesia. Penyebab ini karena pengurusan pabrik di urus oleh oleh Semen Indonesia maka dari itu semua kebijakan yang di atur oleh Semen Indonesia maka dari itu masyarakat sangat berdampak akibat perubahan ini.

\section{Daftar Pustaka}

Andriani, I. (2015). Dampak Pembagunan Industri terhadap Diverifikasi Mata Pencarian Interaksi Sosial, dan Pendidikan pada Masyarakat Pedesaan. Perspektif Sosiologi, 3, 136.

Bungin, B. (2001). Metode Penelitian Kualitatif Aktualisasi Metodologis ke arah Ragam Varian Kontemporer. (Rajawali P).

Coleman, G. R. \& D. . (2011). teori sosiologi modern.

Hafidh fitriana rofi. (2012). dampak sosial ekonomi munculnya industri kayu.

Handoko suryo,putri nilda, jonrinaldi. (2017). penerapan metode samling kerja di biri pengadaan barang $P T$ Semen Padang.

Moeleong, L. . (2002). Metode Penelitian Kualitatitf (Remaja Ros).

Nanang martono. (2012). Sosiologi Pespektif Sosial (Rajawali).

Nawawi Imam. (2014). pengaruh keberadaan industri terhadap kondisi sosial ekonomi dan budaya masyarakat.

Nurkolis noviani. (2015). dampak keberadaan industri terhadap kondisi sosial ekonomi masyarakat serta lingkungan sekitar industri.

Parker, dkk. (1992). sosiologi industri. PT. Rineka Cipta.

Sugiyono. (2012a). Memahami Penelitian Kuantitatif (Alfabeta).

Sugiyono. (2012b). Metode Penelitian Kuantitatif, Kualitatif dan $R \& D$ (Bandung (ed.)). ALFABETA. 
Sulastri Rina. (2020). persepsi masyarakat terhadap dampak aktivitas pabri PT Semen Padang di Kelurahan Padang Besi Kecamatan Lubuk Kilangan Kota Padang.

Sutedi, D. (2009). Penelitian Pendidikan Bahasa Jepang (Humaniora).

Suwarsono, A. Y. S. (1991). Perubahan sosial dan pembangunan di indonesia.

Tamara, F. (2019). Dampak Pembaguan Kawasan Industri Kendal Pada Perekonomian Masyarakat Dalam Perspektif Ekonomi Islam. 1. 